\title{
A tradução como "exposição" do texto original
}

Georg Otte ${ }^{1}$

Faculdade de Letras, Universidade Federal de Minas Gerais, Belo Horizonte, MG, Brasil

\begin{abstract}
Resumo: Em seu ensaio "A tarefa do tradutor", Benjamin se empenha em mostrar que a tradução não é um simples derivado do original, mas a "expõe" ao leitor. Contestando qualquer função comunicativa do texto literário, ele nega também para a tradução deste texto uma função meramente intermediadora. A tradução não abre um canal de acesso ao original, mas ambos são partes de um todo maior que convergem na "pura língua".
\end{abstract}

Palavras-chave: Walter Benjamin; A tarefa do tradutor.

Title: The Translation as "exposition" of the original text

Abstract: In his essay "The task of the translator", Benjamin aims to show that the translation is not a simple sequel product of the original text, but "exposes" the latter to the reader. Denying the communicative function of the literary text, he also denies an intermediate function of its translation, which does not open an access channel to the original text, since both are parts of a major totality, converging in "pure language".

Keywords: Walter Benjamin; The Task of the Translator.

"Em hipótese alguma, levar em consideração o receptor de uma obra de arte ou de uma forma artística revela-se fecundo para o seu conhecimento." (BENJAMIN, 2011, p. 101) $A$ radicalidade com que Benjamin defende sua posição nesta frase inicial do seu ensaio "A tarefa do tradutor" parece ser inigualável. Trata-se de uma posição ipsis litteris, pois Benjamin simplesmente põe - ou expõe - uma afirmação, isto é, uma "tese" no sentido original do termo grego, pois thésis se refere, segundo as explições etimológicas do dicionário Houaiss, à "ação de colocar, de arranjar, de pôr em algum lugar [...]" (HOUAISS).

A radicalidade dessa posição é reforçada por uma negação: "Em hipótese alguma ...", é a tradução (adequada) de "nirgends" ("Nirgends erweist sich ein Kunstwerk ..."), que significa, literalmente, "em lugar algum". A radicalidade é reforçada porque, do ponto de vista pragmático - ou pragmalinguístico - qualquer negação, para ser relevante, pressupõe a existência de uma afirmação, ou pelo menos, de uma opinião vigente. No caso de Benjamin, a negação se volta contra a opinião amplamente difundida segundo a qual simplesmente não há obra de arte sem receptor. Cabe observar que Benjamin nega uma posição que fará carreira

\footnotetext{
${ }^{1}$ Professor Titular na Faculdade de Letras da Universidade Federal de Minas Gerais, Departamento de Línguas Anglo-Germânicas. Orcid: https://orcid.org/0000-0002-4276-1778 E-mail: georg.otte@uol.com.br
} 
50 anos depois da publicação do seu texto, quando a Estética da Recepção dominaria os estudos literários na Alemanha, atribuindo ao receptor um papel de grande importância.

A radicalidade da frase de abertura, no entanto, esconde ao mesmo tempo uma outra afirmação, desta vez pressuposta pelo próprio autor. Benjamin nega a consideração pelo receptor, mas pressupõe ao mesmo tempo a hipótese, nada óbvia, de a obra de arte contribuir para o conhecimento ou, como Benjamin diz, revelar-se "fecunda" ao conhecimento. A tese esconde uma hipótese, que, mais uma vez recorrendo ao dicionário Houaiss, literalmente, significa "ação de pôr embaixo", ou seja, uma "su(b)posição", ou ainda: uma suposição subentendida.

"Em hipótese alguma ..." - a expressão que introduz o ensaio de Benjamin é uma fórmula quase trivial em português e quem usa essa fórmula certamente não pensa em seu uso no âmbito teórico e muito menos em sua etimologia. No entanto, a reflexão sobre a origem dessa palavra, estimulada pela tradução do ensaio de Benjamin, complementa, de maneira inesperada, a nossa reflexão sobre tese e hipótese, sobre posição e negação. Partimos de uma afirmação de Benjamin em forma de tese, traduzida adequadamente para o português, sendo que essa tradução deu às nossas reflexões uma direção que, sem ela, provavelmente não teriam tomado.

O verbo "por", em alemão, varia de acordo com a posição concreta em que o objeto é posto; basicamente, temos a escolha entre a posição horizontal (legen) e a vertical (stellen). Portanto, posso usar os dois verbos para o mesmo objeto, dependendo da posição em que se encontra. Todavia, esse objeto fica mais exposto em posição vertical, como, por exemplo, numa ex-posição (Aus-stellung, em alemão). E uma tese como aquela citada de Benjamin, fica, sem dúvida, mais exposta logo no início de um texto, sendo que, em alemão, uma afirmação não é simplesmente feita, porém "erguida" (aufgestellt).

A nossa comparação entre verbos alemães com o radical stellen é mais que um jogo de palavras: como ainda será exposto, o próprio Benjamin joga com o sentido literal e metafórico desse verbo, que, no contexto das reflexões iniciais, serve para apresentar a escrita de Benjamin como "vertical" e, consequentemente, como um ato de resistência contra o fluxo linear - ou "horizontal" - do discurso habitual. O nosso pensador não argumenta de forma indutiva ou dedutiva, concatenando as frases através conjunções causais ou finais, mas "põe" uma afirmação ao lado da outra, substituindo a subordinação operada por aquelas conjunções pela justaposição de orações simples, em alguns casos sem nexo aparente.

A oposição entre vertical e horizontal que utilizamos para distinguir entre o discurso "tético" de Benjamin e o discurso linear-argumentativo não deixa de remeter ao antológico ensaio "A cicatriz de Ulisses", de Erich Auerbach, quando compara o texto homérico ao bíblico, elaborando, de forma magistral, a distinção fundamental entre os dois tipos de discurso: 
Quanto mais isolados e horizontalmente independentes são os relatos e os grupos de relatos [do Velho Testamento], se comparados com os da llíada e da Odisséia, tanto mais forte é a sua ligação vertical comum que os mantém todos juntos sob um mesmo signo, o que falta totalmente a Homero. Em cada uma das grandes figuras do Velho Testamento, desde Adão até os Profetas, encarna-se um momento da mencionada ligação vertical. (AUERBACH, 1987, p. 14; grifo nosso)

Evidentemente, as referências de Auerbach são arcaicas, mas não deixam de refletir uma oposição de princípios que Adorno, com referências constantes a Benjamin, retomaria em seus textos "A forma do ensaio" (ADORNO, 2003) e "Parataxis" (ADORNO, 1981), lançando mão, respectivamente, de dicotomias análogas como aquelas entre o dinâmico e o estático, e ainda entre hipotaxe e parataxe, sendo que o primeiro elemento desses pares de opostos corresponde ao fluxo horizontal e o segundo à resistência vertical a esse fluxo. A relação aparentemente desconexa que Auerbach constata entre os relatos da Bíblia e a oposição à narrativa homérica também diz respeito à sequência linear das orações, pois, no caso de Homero, o nexo entre elas, "a ligação sintática entre as partes é perfeitamente clara" (AUERBACH, 1987, p. 2). A oposição entre vertical e horizontal perpassa todos os níveis.

Se a ligação horizontal-sintática entre os elementos é garantida pelas próprias regras gramaticais, a expressão "ligação vertical", usada por Auerbach, causa certas dificuldades, uma vez que essa verticalidade é responsável pela falta de uma ligação imediata entre orações e relatos. No entanto, trata-se de uma ligação "sob o mesmo signo" ou então: sob o mesmo Deus, isto é, sob a instância suprema do monoteísmo judaico-cristão para a qual convergem todos os relatos bíblicos apesar de sua relativa independência. Auerbach não entra em questões de ordem teológica, mas a diferença entre monoteísmo e politeísmo está implícita em seu texto. As narrativas da mitologia grega podem ser coesas cada uma por si, mas os conflitos em torno da guerra de Troia e suas reviravoltas refletem as brigas entre os próprios deuses, que, apesar da hierarquia olímpica, não dispõem de uma instância unificadora.

O texto de Benjamin possui essa instância. A questão se um texto pode ou deve ser traduzido não encontra sua resposta na qualificação de um tradutor, isto é, no plano humano, mas na possibilidade de o original e sua tradução convergirem na "rememoração de Deus" (BENJAMIN, 2011, p. 103). O pressuposto de uma "pura língua" pode ser um empréstimo de Mallarmé (MOSÈS, 2015, pos. 872), mas remete ao mesmo tempo a uma esfera divina, isto é, a um fundamento teológico. Esse fundamento, que Benjamin explicita em seu ensaio "Sobre a linguagem em geral e sobre a linguagem do homem" - o próprio título não deixa dúvida quanto à divisão entre uma esfera humana e não humana - projeta uma utopia voltada, paradoxalmente, para um passado anterior à história humana, isto é, ao estado adâmico da linguagem. "O pecado original é a hora de nascimento da linguagem humana" (BENJAMIN, 2011, p. 67) - a "pura linguagem" é a linguagem adâmica do nome, sendo que o "pecado" consiste na degradação da linguagem quando usada como mera ferramenta de comunicação. 
Atribuindo ao texto poético um conceito de "vida", provavelmente sob a influência da filosofia da vida de Wilhelm Dilthey, mas distanciando-se ao mesmo tempo dela (WEIDNER, 2011, p. 169), Benjamin distingue os textos originais de acordo com seu potencial de desdobramento. Recorrendo a metáforas do âmbito da vegetação (semente, germe etc.), ele deixa claro que o original possui vida própria e que seu "amadurecimento" escapa ao controle humano. A tradução seria a forma mais evidente desse desdobramento, pois é nela que essa vida encontraria sua expressão máxima de sua essência. Partindo, mais uma vez, do pressuposto de que todos os fenômenos da vida convergem numa instância superior, Benjamin estabelece também um fim superior para todas as finalidades particulares:

Vida e finalidade: seu nexo [...] é descoberto apenas onde aquele fim, para o qual convergem todas as finalidades da vida, deixa de ser, por sua vez, buscado na esfera própria dessa vida, para ser procurado numa esfera mais elevada. Todas as manifestações da vida que estão em conformidade com fins, bem como a finalidade em geral dessas manifestações, não visam, em última instância, um fim para a vida, mas sim para a expressão [Ausdruck] de sua essência, para a apresentação [Darstellung] de seu significado. Desse modo, a finalidade da tradução consiste, por último, em expressar [für den Ausdruck] o mais íntimo relacionamento das línguas entre si. Ela própria não é capaz de revelar, nem é capaz de instituir [herstellen] essa relação oculta; pode, porém, apresentá-la [darstellen], realizando-a em germe ou intensivamente. E essa apresentação [Darstellung] de um objeto significado pela tentativa, pelo germe de sua produção [Herstellung], é um modo muito peculiar de apresentação [Darstellung], o qual dificilmente pode ser encontrado no âmbito da vida que não seja a vida da linguagem. (BENJAMIN, 2011, p. 105106)

A extensão maior desta citação se justifica pelo jogo que Benjamin desenvolve com os verbos herstellen e darstellen, ambos derivados do radical stellen, que utilizamos para a nossa demonstração inicial e que, nesta última passagem do próprio Benjamin, evidencia outro aspecto do seu discurso apodíctico, que defende, de forma explícita, nas reflexões introdutórias: "Por princípio, a primeira questão só admite uma solução problemática, sendo a da segunda apodíctica." BENJAMIN, 2011, p. 102-103). Poderíamos chamar esse discurso também de "performático", pois a própria repetição dos mesmos verbos e a oposição de dois verbos com a mesma raíz (stellen) põem seu radical em evidência, livrando-o do desgaste sofrido pelo uso comunicativo. Trata-se de um "jogo de palavras" com fundo sério, pois seu caráter lúdico visa o resgate do significado concreto do verbo, que costuma ser ignorado, ou então: descartado como sentido "apenas" literal da palavra.

Cabe lembrar que o ensaio de Benjamin foi concebido, pelo próprio autor, como prefácio de sua tradução dos "Quadros parisienses" ("Tableaux parisiense") de Baudelaire. ${ }^{2}$

\footnotetext{
${ }^{2}$ Benjamin manifesta essa intenção numa carta ao editor R. Weißbach, de 04/12/1920; cf. BENJAMIN, 1991, p. 889-891.
} 
Há outro prefácio de Benjamin, escrito poucos anos depois, que começa com uma tese: “É característico do texto filosófico confrontar-se, sempre de novo, com a questão da representação [Darstellung]." (BENJAMIN, 1984, p. 49). Trata-se da primeira frase do "Prefácio epistemológico" do livro Origem do drama barroco alemão, da "Erkenntniskritische Vorrede", traduzido, no Brasil, por Sérgio Paulo Rouanet. Desta vez, a relação com o conhecimento (Erkenntnis) é explicitada pelo próprio título, que João Barrento, o tradutor português, traduziu como "Prólogo epistemológico-crítico" (BENJAMIN, 2004, p. 13-45). Todavia, os dois tradutores lançam mão do termo "representação" para traduzir Darstellung, tradução esta que pode ser encontrada nos dicionários, mas elimina o sentido "performático" dado por Benjamin.

Como observou Jeanne-Marie Gagnebin a

palavra Darstellung [...] não pode, (aliás, nem deve), ser traduzida por 'representação', [...] nem o verbo darstellen pode ser traduzido por 'representar'. [...] Proponho, então, que se traduza Darstellung por 'apresentação' ou 'exposição', e darstellen por 'apresentar' ou 'expor', ressaltando a proximidade no campo semântico com as palavras Ausstellung (exposição de arte) ou também Darstellung, no contexto teatral (apresentação). (GAGNEBIN, 2005: sem paginação)

Jeanne-Marie Gagnebin rejeita a tradução de Darstellung por "representação" por motivos filosóficos, uma vez que o termo também serviu como tradução de Vorstellung, isto é, da "representação mental de objetos exteriores ao sujeito" (GAGNEBIN, 2005; sem paginação). Certamente não é por acaso que tanto no caso de Darstellung quanto no de Ausstellung há uma proximidade com o ambiente artístico, lembrando que o Darsteller é simplesmente um sinônimo de ator e que o prefácio em questão está, para ampliar mais um pouco a família lexical de -stellen, anteposto (vorangestellt) a um texto sobre o teatro barroco. Os dois prefácios, aliás, não prefaciam os respectivos textos no sentido de antecipar alguma coisa que fosse desenvolvido posteriormente. "A tarefa do tradutor" não menciona, em momento algum, o nome de Baudelaire e o longo "Prefácio epistemológico" contém apenas duas ou três breves referências ao teatro barroco. Neste último prefácio, Benjamin se mostra muito mais preocupado em questionar os procedimentos lógicos da dedução e da indução, do que em fornecer reflexões preliminares sobre a história do teatro barroco na Alemanha: "Enquanto a dedução degrada as ideias em conceitos, renunciando à sua articulação e ordenação, a dedução chega aos mesmo resultados através da sua projeção num continuum pseudo-lógico." (BENJAMIN, 2004, p. 29).

Os "prefácios que não prefaciam" são apenas mais um exemplo para o grande "adversário" do pensamento benjamiano, a saber o "continuum", que ele condena em três teses seguidas (teses 14 a 16; BENJAMIN, 2012, p. 249-250) do seu último texto, intitulado "Sobre o conceito de história". Mais conhecido, simplesmente, como "Teses", esse texto, por si só, é uma demonstração de não continuidade, isto é, de uma sequência de fragmentos 
aparentemente desconexos, que, no entanto, se complementam mutuamente. É "erguendo teses", para imitar a expressão alemã Thesen aufstellen, que Benjamin, em 1940, transforma as "intermitências", que defendia em 1925 para a forma do tratado (BENJAMIN, 1984, p. 50), em "explosões" que destroem o "continuum". Esse ato, à primeira vista, destrutivo se revela como libertador, pois possibilita a construção de uma outra história a partir dos fragmentos, representados pela própria forma fragmentária das teses. As teses são a apresentação performática dos escombros que, na nona tese, o anjo da história procura juntar à maneira dos cacos dos vasos quebrados, de acordo com a narrativa do mito judaico Tikun Olam ${ }^{3}$, tendo sua tentativa frustrada, entretanto, pela "tempestade que chamamos progresso", isto é, pela ideologia de uma história linear. Resta a promessa da reconstituição de uma história, composta de fragmentos, porém formando um todo, da mesma maneira que original e tradução, assim como todas as línguas, "são fragmentos de uma língua maior, como cacos são fragmentos de um vaso." (BENJAMIN, 2011, p. 115)

Mas o drama barroco não seria a Darstellung, no melhor sentido teatral da palavra, de um pensamento não linear? E o próprio Benjamin não demonstra com o próprio prefácio que a relação entre a reflexão epistemológica e o tratamento do assunto concreto também não pode ser feito na forma de uma sequência linear? Os fenômenos concretos não podem ser deduzidos simplesmente das ideias, sempre há uma ruptura entre o reino ideal e o material, motivo pelo qual Benjamin defende que se contemple "um mesmo objeto nos vários estratos de sua significação", o que justificaria a já mencionada "intermitência do seu ritmo". Essa intermitência certamente pode ser vista como a marca da própria escrita benjaminiana, que não apenas se caracteriza por pequenas rupturas, mas também por grandes lacunas - como aquela entre o prefácio e o respectivo corpo do texto. A própria escrita do nosso filósofo é a encenação - ou então: performance, ou ainda: Darstellung - de um pensamento que procura encontrar sua realização análoga numa escrita "vertical".

No ensaio em questão, o postulado da verticalidade culmina na defesa da tradução literal, que Benjamin explicita mediante as traduções de Sófocles por Hölderlin, consideradas "exemplos monstruosos de tal literalidade" (BENJAMIN, 2011, p. 114). No entanto, Benjamin defende Hölderlin por não ter traduzido o original por intermediação de um suposto sentido, adaptando o texto grego à sintaxe alemã ou então: germanizando o grego, conforme a crítica de Pannwitz (BENJAMIN, 2011, p. 116-117). Mantendo a estrutura gramatical da língua grega, Hölderlin certamente causou muito estranhamento entre seus leitores, mas permitia aos mais compreensíveis de "juntar os cacos" e de recompor o texto a partir dos fragmentos deixados. O modelo dessa tradução literal seriam as traduções interlineares da Bíblia ${ }^{4}$, nas quais os tradutores também, seja por motivos didáticos, seja por considerarem o texto sagrado como "intocável", mantinham em sua tradução a ordem sintática do original colocando, em ordem vertical, palavra debaixo de palavra, contrariando, evidentemente as regras gramaticais da

\footnotetext{
${ }^{3}$ A adaptação ortográfica ao alfabeto latino varia entre Tikun, Tikkun, Tiqun e Tiqqun.

${ }^{4}$ Como exemplo de uma tradução interlinear, cf. a tradução da Bíblia do hebraico para o inglês em https://www.scripture4all.org/Onlinelnterlinear/Hebrew Index.htm
} 
língua-alvo em seu fluxo horizontal. Mais uma vez, Benjamin provoca com uma tese heterodoxa e, mais uma vez, ela consta em local exposto, desta vez no final do texto: "A versão interlinear do texto sagrado é o arquétipo ou ideal de toda tradução." (BENJAMIN, 2011, p. 119)

A encenação da escrita que Benjamin não apenas defende, mas também pratica em seu prefácio mediante uma linguagem "intermitente" faz parte do projeto da Darstellung, em que o texto filosófico não se limita à função simbólica ou puramente referencial das palavras, mas no qual a própria estruturação do texto passa a ser uma demonstração daquilo que defende no plano simbólico. Qualquer palavra pode desempenhar uma função simbólica quando se refere a uma totalidade de objetos como no caso da palavra "pão", para usar o exemplo levantado por Benjamin. Ela pode ser usada para referirmos a um pão concreto e presente para o falante, mas também - e esse é o caso mais comum - a um pão ausente de uma situação de diálogo, o que nos obriga a recorrer ao conceito de pão, isto é, às características mínimas para fins comunicativos. Basta consultar o dicionário para conhecer esse conceito: "alimento feito com farinha, esp. de trigo, amassada com água e fermento e assada ao forno" (HOUAISS). São esses traços semânticos, em termos linguísticos, ou é esse denominador comum, em termos matemáticos, que definem o conceito 'pão' e que permitem que as pessoas se referem a ele como um universal amplamente conhecido.

Essa representação simbólica faz parte do "programa" minimalista das ciências, que, evidentemente, são obrigados a recorrer a conceitos transparentes e que substituem as palavras por símbolos mais simples como a, b, c ou x, y, z, como acontece na álgebra ou na lógica. Para a lógica, não apenas o significado é perfeitamente substituível - a definição do dicionário monolíngue vale tanto para o pão sírio quanto para o pão francês -, mas também o significante, como mostra o dicionário bilingue: "pão" é igual a Brot (bread, pain, etc). A redução da nossa realidade operada pela lógica e a redução da nossa linguagem operada pelos dicionários a denominadores comuns levou filósofos da linguagem e linguistas a proclamar a arbitrariedade da palavra, uma vez que tanto as palavras quanto as coisas seriam substituíveis entre si.

No entanto, sabemos que entrar numa padaria em Paris e pedir um pão gera um resultado diferente do que em Bruxelas e pedir uma cerveja em Munique gera um resultado diferente do que em Berlim. Em cada cultura, mesmo quando a língua é a mesma, o nome, apesar de ser genérico, não designa um conceito universal - com licença do pleonasmo, pois um conceito, para ser um conceito, tem que ser universal. Ele designa determinado tipo de pão ou determinado tipo de cerveja, aproximando-se, assim, dos nomes próprios, que, por serem próprios do objeto designado, não são intercambiáveis. A linguagem dos nomes (ou linguagem "adamítica") que Benjamin defende em seu ensaio "Sobre a linguagem em geral e a linguagem do homem", é o contrário a posições como aquela de Saussure, pois nela, a um vínculo entre as palavras e as coisas. Em última instância, Benjamin rejeita a separação entre os dois planos significante e significado, pois as palavras, em sua função performática, 
justapostas, opostas e ainda sobrepostas devido à sua repetição, ganham materialidade quando desempenham um papel no sentido teatral da palavra.

Como se não bastasse rejeitar as opiniões vigentes, Benjamin, quando defende uma ideia, recorre a um esoterismo que, por definição, é de difícil acesso para o leitor comum - e se revela mais difícil ainda para o leitor especializado. No mencionado "Prefácio epistemológico", ele chega a defender esse esoterismo explicitamente (BENJAMIN, 1984, p. 50), distinguindo entre o "visado" (das Gemeinte) e o "modo de visar" (Art des Meinens):

Em "Brot" e "pain" o visado é o mesmo; mas o modo de visar, ao contrário, não o é. Está implícito, pois, no modo de visar o fato de que ambas as palavras significam algo diferente para um alemão e um francês, respectivamente; que, para eles, elas não são intercambiáveis e que, aliás, em última instância, almejem excluir-se mutuamente; porém, no que diz respeito ao objeto visado, tomadas em termos absolutos, elas significam a mesma e idêntica coisa. (BENJAMIN, 2011, p. 109)

A passagem citada teria ficado mais compreensível se Benjamin tivesse trabalhado com a distinção entre bedeuten ("significar") e meinen (muitas vezes traduzido por "querer dizer"): posso entender o significado de uma palavra da maneira que o dicionário a define, mas não o que a pessoa quer dizer com ela. A diferença fica mais clara quando escrevemos uma carta - ou um e-mail - numa língua da qual temos apenas conhecimentos iniciais com a ajuda do dicionário: apesar de utilizar o significado correto, o nosso destinatário pode não entender o que queremos dizer quando falamos de um "vidro de cerveja" (ein Glas Bier). Adorno, em "O ensaio como forma", provavelmente falando de sua experiência de exílio nos Estados Unidos, também recorre a essa armadilha do dicionário, isto é: do conceito, mostrando como uma pessoa "em terra estrangeira" se apropria do significado de uma palavra a partir do seu uso concreto: "Essa pessoa vai ler sem dicionário. Quando tiver visto trinta vezes a mesma palavra, em contextos sempre diferentes, estará mais segura de seu sentido do que se tivesse consultado o verbete com a lista de significados [...]." (ADORNO, 2003, p. 30)

Para os cientistas e para os hipotéticos especialistas em panificação, Brot e pain, "em termos absolutos, [...] significam a mesma e idêntica coisa" (BENJAMIN, 2011, p. 109). E nos hipotéticos congressos dos panificadores, todos entendem do assunto e sabem de que se fala e, quando divergem em certos pontos, conseguem se comunicar. Mesmo reconhecendo a grande variedade de pães e discutindo as diferenças, as categorias e subcategorias sempre são reduzidas aos seus denominadores comuns. Para o especialista, não pode sobrar uma migalha que fizesse a diferença, pois, sem a redução aos traços semânticos mínimos, a comunicação entre os congressistas não seria possível ou apresentaria muitos "ruídos". A comunicação bem-sucedida, portanto, se baseia em conceitos "claros e distintos", para citar o bordão de Descartes. Coincidência ou não, Adorno, logo após sua recusa de usar o dicionário no referido ensaio e sua defesa de uma aprendizagem "por fragmentos empíricos", questiona 
quatro regras que Descartes estabelece no seu Discurso do método (ADORNO, 2003, p. 3134). "O ensaio como forma" acaba sendo um verdadeiro panfleto anticartesiano, pois põe em prática, à maneira de Benjamin, por meio da forma do texto, aquilo que postula como conteúdo teórico. Trata-se de um "meta-ensaio", um ensaio sobre o ensaio, que anula e sintetiza ao mesmo tempo - no sentido da Aufhebung ("suprassunção") hegeliana - a dicotomia tradicional entre forma e conteúdo. Segundo Adorno, Benjamin foi o "mestre insuperável" desta prática teórica.

Trata-se, no entanto, de uma "dialética negativa", jogando com o título do livro de Adorno, pois a dicotomia forma e conteúdo, na verdade, não chegam a uma síntese no sentido de uma homogeneização operada pelo conceito. O discurso "vertical", mesmo vislumbrando uma totalização, não é "totalitário", motivo pelo qual Adorno "troca" Hegel por Nietzsche. Em uma conferência do semestre de verão de 1963, Adorno diz que sua maior dívida, entre os "chamados grandes filosóficos", seria aquela com Nietzsche, "talvez mais do que com Hegel" (ADORNO apud PICHLER 2017, p. 231). Essa dívida se torna compreensível na leitura de "Sobre verdade e mentira no sentido extra-moral", onde Nietzsche, recorrendo ao exemplo de uma folha, não deixa dúvida quanto ao preço alto que pagamos para chegar à transparência "clara e distinta" do conceito: "Todo conceito surge pela igualação do não-igual. Tão certo como uma folha nunca é totalmente igual a uma outra, é certo ainda que o conceito de folha é formado por meio de uma arbitrária abstração dessas diferenças individuais [...]" (NIETZSCHE, 2007, p. 35). A dívida de Adorno com Nietzsche, aliás, se torna ainda mais óbvia numa outra tradução que recorre ao conceito adorniano do "não-idêntico" (das Nichtidentische) para falar do "nãoigual": "Todo conceito surge da postulação da identidade do não-idêntico." (MELO SOBRINHO 2001: 12) Mas é apenas a tradução que "cita" Adorno, pois, no original alemão, ("Jeder Begriff entsteht durch Gleichsetzen des Nichtgleichen." NIETZSCHE, 1997, p. 313), a expressão adorniana não aparece. Enquanto a primeira tradução permite a aproximação entre Nietzsche e Adorno apenas no plano semântico, a segunda, devido ao uso do mesmo termo, estabelece uma relação de identidade mediante o significante. A tradução, neste último caso, não apenas complementa o original pelas conotações contidas na língua-alvo, mas gera relações que vão além dele.

A tradução, portanto, não consiste na criação de conceitos equivalentes, o que seria uma ampliação da "mentira extra-moral", isto é, da mentira epistemológica com a negação decorrente das diferenças individuais. "Mentimos" quando usamos as palavras para designar conceitos, sendo os cientistas - e não apenas os botânicos - os maiores "mentirosos", pois falam em folhas e outros objetos que, na forma idealizada pelo conceito, não existem. Mentiríamos mais ainda se achássemos que uma folha europeia seja igual à folha de uma árvore tropical.

O exemplo de Nietzsche, evidentemente, é suspeito, pois, na natureza, uma folha certamente nunca é igual à outra. E o exemplo do pão vale para o pão artesanal, feito com as mãos, mas não para o pão industrial fabricado na "era de sua reprodutibilidade técnica", para citar outro famoso ensaio de Benjamin. Nele, o nosso pensador fala da transição da obra de 
arte feita à mão para a obra "tecnicamente reprodutível", isto é, da obra singular ("nãoidêntica") que perdeu sua singularidade por ser produzida - ou reproduzida - sempre igual, em escala industrial. Como muitos comentadores já observaram, trata-se do ponto mais questionável do ensaio, pois sabemos que tanto a obra plástica, quanto a literária não perderam sua singularidade com sua reprodutibilidade técnica, nem com a digital: "A aura, definitivamente, não desapareceu, conforme Benjamin antecipou; pelo contrário, ela, na verdade, conquistou o campo da reprodução técnica. O cinema não se transformou no medium com o qual estava sonhando; [...]." (GUMBRECHT; MARRINAN 2003: XIV; trad. G. O.). ${ }^{5}$

Sem dúvida, Benjamin estava se referindo à reprodução técnica de imagens, e não de textos. No entanto, não há como não levantar a questão da reprodutibilidade técnica também para a obra literária, que, apesar de envolver "transformações gigantescas", o nosso pensador evita analisar com a justificativa um tanto evasiva de se tratar "apenas de um caso especial" (BENJAMIN, 2012, p. 180). De qualquer forma, no ensaio de 1921, ele parte do pressuposto de a obra de arte em geral, e a obra poética em particular, serem únicas e sua "sobrevida" ou "pervivência" fazer parte de uma aura quando fala do "inapreensível, o misterioso, o 'poético'" (BENJAMIN, 2011, p. 101). Cabe lembrar que, antes de entrar na questão da tradução no segundo parágrafo do ensaio, Benjamin fala da obra em geral e de sua relação com o receptor, radicalizando sua posição, já bastante radical, quando diz: "Nenhum poema dirige-se, pois, ao leitor, nenhum quadro, ao espectador, nenhuma sinfonia, aos ouvintes." (BENJAMIN, 2011, p. 101). É exatamente o contrário dos seus postulados - também em forma de teses - por uma apropriação da obra pelo receptor, facilitada pela sua reprodutibilidade. A rejeição explícita da função comunicativa tanto da obra literária, que remonta a condenação dessa função na sua filosofia da linguagem, vale também para a sua tradução, que não reproduz o original, mas o complementa.

A tradução pode ser vista como uma forma de reprodução. Enquanto lidamos com traduções técnicas ou científicas, essa reprodução pode não ser fácil devido à especificidade do assunto tratado, mas acaba sendo possível devido à delimitação concisa dos conceitos utilizados - desde que não apareçam metáforas. Sabemos que, mesmo os textos técnicos, que não costumam brilhar pelos seus elementos poéticos, falam em "dentes", "cabeças", "pés" e outras partes do corpo no "sentido figurado", como se diz, que normalmente não pode ser traduzido literalmente. A cabeça de um prego também é uma cabeça (Kopf) em alemão; já a orelha de um livro cria sérios problemas ao tradutor - pelo menos para um alemão.

A metáfora pode passar por um processo de desgaste, como no caso de "cabeça", que acaba sendo reduzida ao significado "parte superior". Jacques Derrida, em seu ensaio "A mitologia branca", fala desse desgaste recorrendo ao escritor francês Anatole France. No diálogo deste último, intitulado O jardim de Epicuro (Le jardin d'Épicure), um dos personagens

\footnotetext{
5 "Aura has definitely not disappeared as Benjamin anticipated; rather, it has actually conquered the field of art's technical reproduction. Film has not developed into the critical medium about which he was dreaming; [...]".
} 
compara as palavras a moedas antigas, cuja efígie é gasta pelo uso. No decorrer do tempo, as metáforas também perdem sua plasticidade - e,com isso, sua singularidade - e acabam tendo uma superfície lisa, uma "lisura" - agora no sentido metafórico - que é cobrada do conceito científico para passar, sem "ruído", pelos estreitos canais de comunicação. Como mostrou Blumenberg em seus Paradigmas para uma metaforologia (Paradigmen zu einer Metaphorologie - BLUMENBERG, 1997), a maioria dos nossos conceitos nada mais são do que metáforas "alisadas".

Qualquer objeto concreto, com seu apelo à percepção sensorial é singular, inclusive a representação mental dessa percepção (Vorstellung) e sua apresentação por outros meios que apelam aos sentidos, isto é, por imagens ou pela sua apresentação textual (Darstellung). Por uma questão de economia de esforço, reduzimos esses objetos aos seus "traços mínimos" dentro de um contexto funcional que se reflete no uso instrumental da linguagem. $O$ uso mais ou menos original da metáfora escapa desse contexto e desse uso, pois, ao invés de reduzir o objeto singular ao conceito, o amplia por uma imagem não menos singular. A metáfora, enquanto "recurso performático", não é um "enfeite" adicional do texto literário, mas o texto literário é, ele mesmo, genuinamente metafórico por projetar imagens singulares. "A tarefa do tradutor" se restringe rigorosamente ao tradutor literário em sua "tarefa" de ampliar o olhar para o mundo ao invés de reduzi-lo estabelecendo conceitos supostamente "claros e distintos". Em suas Meditações, Descartes recorre à ilusão de ótica para mostrar como os nossos cinco sentidos nos enganam; para Benjamin (e Adorno), inspirados por Nietzsche, é a comunicação baseada em conceitos que nos ilude, pois é a exposição do texto-objeto aos nossos sentidos que lhe conferem sentido.

\section{Referências}

ADORNO, Theodor W. O ensaio como forma. Notas de literatura. Trad. Jorge de Almeida. São Paulo, Livraria Duas Cidades; Editora 34, 2003. p. 15-46.

ADORNO, Theodor W. Parataxis. Noten zur Literatur. Frankfurt, Suhrkamp, 1981. S. 447-491.

AUERBACH, Erich. A cicatriz de Ulisses. Mimesis. A representação da realidade na literatura ocidental. 2. Ed. revisada. São Paulo: Perspectiva, 1987. p. 1-20.

BENJAMIN, Walter. A obra de arte na era de sua reprodutibilidade técnica. In: BENJAMIN, Walter. Magia e técnica, arte e política. Ensaios sobre literatura e história da cultura. Tradução: Sérgio Paulo Rouanet. 8. ed. revista. São Paulo: Brasiliense, 2012 (Obras escolhidas, v. I). p. $179-212$.

BENJAMIN, Walter. A tarefa do tradutor. In: BENJAMIN, Walter. Escritos sobre mito $e$ linguagem (1915-1921). Organização, apresentação e notas de Jeanne Marie Gagnebin. Trad. de Susana Kampff Lages e Ernani Chaves. São Paulo: Duas Cidades; Editora 34, 2011. p. 101119.

BENJAMIN, Walter. Die Aufgabe des Übersetzers. In: BENJAMIN, Walter. Kleine Prosa. Baudelaire-Übertragungen. Frankfurt/M.: Suhrkamp, 1991. [Gesammelte Schriften, Bd. 4] 
BENJAMIN, Walter. Escritos sobre mito e linguagem (1915-1921). Organização, apresentação e notas de Jeanne Marie Gagnebin. Trad. de Susana Kampff Lages e Ernani Chaves. São Paulo: Duas Cidades; Editora 34, 2011.

BENJAMIN, Walter. Sobre a linguagem em geral e sobre a linguagem do homem. In: BENJAMIN, Walter. Escritos sobre mito e linguagem (1915-1921). Organização, apresentação e notas de Jeanne Marie Gagnebin. Trad. de Susana Kampff Lages e Ernani Chaves. São Paulo: Duas Cidades; Editora 34, 2011. p. 49-73.

BENJAMIN, Walter. Kleine Prosa. Baudelaire-Übertragungen. Frankfurt/M.: Suhrkamp, 1991. [Gesammelte Schriften, Bd. 4]

BENJAMIN, Walter. Origem do drama barroco alemão. Tradução, apresentação e notas: Sérgio Paulo Rouanet. São Paulo: Brasiliense, 1984.

BENJAMIN, Walter. Origem do drama trágico alemão. Trad. João Barrento. Lisboa: Assírio \& Alvim, 2004.

BLUMENBERG, Hans. Paradigmen zu einer Metaphorologie. Frankfurt/M.: Suhrkamp, 1997.

DERRIDA, Jacques. A mitologia branca. In: DERRIDA, Jacques. Margens da filosofia. Trad. Joaquim Torres Costa; Antônio M. Magalhães. Campinas: Papirus, 1991. p. 249-314.

DESCARTES, René. Discurso do método; As paixões da alma; Meditações. São Paulo: Nova Cultural, 1999.

Dicionário HOUAISS [versão eletrônica]. https://houaiss.uol.com.br/pub/apps/www/v33/html/index.php\#1.

GAGNEBIN, Jeanne Marie. Do conceito de Darstellung em Walter Benjamin ou: verdade e beleza. Kriterion, v. 46, n. 112, dez. 2005. https://doi.org/10.1590/S0100$\underline{512 \times 2005000200004}$

GUMBRECHT, Hans Ulrich; MARRINAN, Michael. Mapping Benjamin. The Work of Art in the Digital Age. Stanford, Cal.: Stanford Univ. Press, 2003.

HEBREW INTERLINEAR BIBLE (OT). Disponível em: https://www.scripture4all.org/Onlinelnterlinear/Hebrew Index.htm. Acesso em: 11 mai. 2019.

MELO SOBRINHO, Noéli Correia de. Friedrich Nietzsche: Verdade e Mentira no Sentido Extramoral. Comum (Rio de Janeiro), Rio de Janeiro, v. 6, n.17, p. 5-23, 2001.

MOSÈS, Stéphane. Walter Benjamin et l'esprit de la modernité. Éditon établie et présentée par Heinz Wismann. Paris: Les Éditions du Cerf, 2015. [Edição Kindle]

NIETZSCHE, Friedrich. Sobre verdade e mentira. São Paulo: Hedra, 2007.

NIETZSCHE, Friedrich. Über Wahrheit und Lüge im außermoralischen Sinn. In: NIETZSCHE, Friedrich. Werke in drei Bänden. Vol. 3. Darmstadt: Wissenschaftliche Buchgesellschaft, 1997. S. 309-322.

PICHLER, Axel. 'eine antimetaphysische aber artistische' Philosophie. Adornos Inanspruchnahme Nietzsches und anderer Quellen in einer Einfügung zur Ästhetischen Theorie. In: ENDRES, Martin; PICHLER, Axel; ZITTEL, Claus (orgs.). Text/Kritik: Nietzsche und Adorno. Berlin; Boston: de Gruyter, 2017. p. 231-272. https://doi.org/10.1515/9783110304053-006 
WEIDNER, Daniel. Fort-, Über- und Nachleben. Zu einer Denkfigur bei Benjamin. In: WEIDNER, Daniel; WEIGEL, Sigrid. Benjamin-Studien, vol. 2. Munique: Fink, 2011. https://doi.org/10.30965/9783846750711

Recebido em: 20/05/2019

Aceito em: 02/07/2019 